P-ISSN 2442-6636

E-ISSN 2355-3987

www.ijhn.ub.ac.id

Artikel Hasil Penelitian

\title{
Pengaruh Pemberian Jus Jambu Biji Merah (Psidium guajava) dan Jeruk Siam (Citrus nobilis) terhadap Kadar High Density Lipoprotein (HDL) pada Pasien Dislipidemia
}

\section{(The Effect of Guava Extract (Psidium guajava) and Siam Citrus Fruit (Citrus nobilis) on HDL Level in Dyslipidemic Patients)}

\author{
Dewinta Hayudanti ${ }^{1}$, Inggita Kusumastuty ${ }^{1}$, Kanthi Permaningtyas Tritisari $^{1}$ \\ 1 Program Studi Ilmu Gizi Fakultas Kedokteran Universitas Brawijaya \\ * Alamat korespondensi, E-Mail: dewintahayudanti555@gmail.com
}

Diterima: / Direview: / Dimuat: Februari 2015/ Juli 2015/ Juni 2016

\begin{abstract}
Abstrak
Penurunan kadar HDL merupakan salah satu tanda yang terjadi pada penderita dislipidemia. Pada penderita dislipidemia, serat memiliki peranan penting sebagai arteroprotektif. Penelitian ini bertujuan untuk membuktikan bahwa pemberian jus jambu biji merah dan buah jeruk siam dapat memenuhi kebutuhan hingga 21,5 g serat/hari (serat larut air) sehingga dapat meningkatkan kadar HDL. Study quasi experimental ini menggunakan desain pre-post test control group yang dilakukan terhadap pasien dislipidemia di Puskesmas Cisadea Kota Malang. Sampel dipilih secara non probability yang dibagi dalam dua kelompok yaitu kelompok kontrol $(\mathrm{n}=16)$ yang hanya diberikan konseling gizi saja dan kelompok perlakuan $(n=16)$ yang diberikan konseling gizi serta jus jambu biji merah dan buah jeruk siam yang diintervensi selama 14 hari. Hasil penelitian ini menunjukkan bahwa terdapat peningkatan selisih kadar HDL dari pemberian jus jambu biji merah dan buah jeruk siam antara kelompok kontrol $\pm 1,06$ dan kelompok perlakuan $\pm 0,06$. Setelah dilakukan analisis menggunakan uji Independent $t$-test, terdapat perbedaan yang signifikan $(\mathrm{p}<0.05)$.
\end{abstract}

Kata kunci: dislipidemia, HDL, jambu biji merah, buah jeruk siam.

\section{Abstract}

Low levels of HDL is a feature in dyslipidemia patient. Fiber has an important role as arteroprotective in dislipidemia patient. The fibers in red guava juice and siam citrus fruit can meet up to $21,5 \mathrm{~g}$ fiber/day. This research aims to prove that fibers increase HDL levels. Quasi experimental study used design pre-post test control group in patient with dislipidemia in Public Health Center Cisadea of Malang City. The sample was selected based on by non probability sampling to be devided into two groups, the control group $(n=16)$ were only given nutritional counseling and treatment $(n=16)$ were given nutritional counseling as well as guava juice and siam citrus fruit who intervention during the 14 days. The results of this research suggest that increased the difference of levels of HDL as an influence of red guava juice and siam citrus fruits between control group $\pm 0,06 \mathrm{mg} / \mathrm{dl}$ and treatment group $1.06 \mathrm{mg} / \mathrm{dl}$, and it show that the comparison of the difference in HDL levels increase between groups, there was a significant different $(p<0,05)$. Conclusions of this research is red guava juice and siam citrus fruit affecting HDL levels significantly. Based on the research results, suggestions for further research are using other foods as a source of fiber.

Keywords: dyslipidemia, $H D L$, red guava, siam citrus fruit. 


\section{PENDAHULUAN}

Dislipidemia merupakan peningkatan konsentrasi kadar Low Density Lipoprotein (LDL) dan kolesterol total serta penurunan kadar High Density Lipoprotein (HDL), yang merupakan faktor penting dalam risiko terjadinya penyakit jantung koroner dan stroke [1]. Menurut hasil Riskesdas tahun 2013, terdapat 35,9\% penduduk di Indonesia yang memiliki gangguan kolesterol total, 15,9\% memiliki kadar LDL tinggi, 11,9\% memiliki kadar TG tinggi, dan $22,9 \%$ memiliki kadar HDL rendah $(<40 \mathrm{mg} / \mathrm{dl})$ [2]. Menurut DinKes Kota Malang tahun 2013, total penderita dengan gangguan profil lipid baik LDL, TG, kolesterol total, dan HDL mencapai 741 orang. Puskesmas Cisadea merupakan puskesmas dengan persentase pasien dengan gangguan profil lipid paling tinggi yaitu $31,71 \%$ dengan jumlah laki-laki sebanyak 96 orang dan perempuan 139 orang [3].

Partikel HDL berperan penting dalam transport balik kolesterol (Reverse Cholesterol Transfer/RCT), yaitu suatu proses dimana kelebihan kolesterol dalam jaringan perifer dikembalikan ke hati untuk dieksresikan. Proses inilah yang sering disebut sebagai mekanisme utama HDL untuk melindungi tubuh dari risiko aterosklerosis dan bahkan dapat menurunkan regresi plak [4]. Hal inilah yang menjadi penyebab bahwa konsentrasi HDL sangat penting dalam tubuh.

Dislipidemia hingga saat ini hanya dikendalikan dengan terapi obat, namun di sisi lain terdapat terapi diet yang lebih mudah, murah, dan aman yaitu mengkonsumsi serat sehingga lebih dianjurkan. American Association of Clinical Endocrinologist (AACE) tahun 2012 menyatakan bahwa seseorang dengan dislipidemia membutuhkan serat larut air sebanyak 10-25 gram/hari dan serat tidak larut air dibutuhkan rata-rata 2 gram/hari [5]. Namun, berdasarkan hasil survei Pemantauan Konsumsi Gizi (PKG) oleh Direktorat Gizi Masyarakat tahun 2001 dalam Tatang (2011), rata-rata konsumsi serat masyarakat Indonesia hanya sebesar 10,5 gram/orang/hari. Disisi lain, kecukupan serat untuk orang dewasa berkisar antara 25-30 gram/hari, sehingga berdasarkan hasil survei tersebut kecukupan serat orang Indonesia baru mencapai setengah dari kecukupan serat makanan yang dianjurkan. Memperhatikan hal itu, diperlukan perubahan pola konsumsi serat makanan per hari agar dapat mencukupi kebutuhan serat yang dianjurkan [6]. Kebutuhan serat dapat dipenuhi dengan mengonsumsi buah dan sayuran. Dalam penelitian ini, pemenuhan asupan serat diberikan dalam bentuk buah-buahan yaitu buah jambu biji merah dan jeruk siam karena lebih mudah diberikan dan mudah ditemui di daerah Malang.

Penelitian yang dilakukan oleh Astawan tahun 2013 menyatakan bahwa terapi jus buah jambu biji merah dengan dosis $650 \mathrm{mg} / \mathrm{kg} \mathrm{BB}$ tiap $200 \mathrm{ml}$ jus jambu biji merah dapat menurunkan kadar LDL secara signifikan dengan rata-rata sebelum dan sesudah perlakuan sebesar $21,96 \%$ [7]. Berdasarkan penelitian yang telah dilakukan oleh Febriyanto tahun 2012, pemberian jus jeruk sebanyak $3 \times 4,5 \mathrm{ml} / \mathrm{hari}$ (pada tikus) yang setara dengan $750 \mathrm{ml} / \mathrm{hari}$ (pada manusia) selama 15 hari dapat meningkatkan kadar HDL sebesar 35,8\%. Penelitian Febrianto tahun 2012 menyarankan untuk melakukan kombinasi jus jeruk dengan makanan yang berbeda [8]. Selain itu, dengan mengonsumsi 1 buah jeruk sehari dapat membantu menurunkan kadar LDL sebesar 15,5\% dan TG sebanyak 27\% [9]. Berdasarkan hal tersebut, penelitian ini bertujuan untuk memberikan penambahan asupan serat sesuai dengan rekomendasi AACE bagi penderita dislipidemia dalam bentuk jus jambu biji merah dan buah jeruk siam untuk meningkatkan kadar HDL pada penderita dislipidemia.

\section{METODE PENELITIAN}

Penelitian ini dilakukan di wilayah kerja Puskesmas Cisadea Kota Malang. Penelitian ini dilaksanakan pada bulan Desember 2014 sampai dengan Januari 2015. Jenis penelitian ini termasuk dalam quasi experimental dengan desain penelitian pre-post test control group design. Pengambilan subyek penelitian dilakukan secara non probability dengan cara convenience sampling. Dalam menentukan kelompok kontrol dan perlakuan digunakan 
metode simple random sampling, dimana kelompok perlakuan adalah kelompok yang diberi konseling gizi, jus jambu biji merah, dan buah jeruk manis, sedangkan kelompok kontrol adalah kelompok yang hanya diberi konseling gizi. Pada penelitian ini, sebelum dilakukan intervensi dilakukan pencatatan makan responden selama 3 bulan terakhir untuk melihat kebiasaan makan responden terutama pada makanan sumber lemak dan serat dengan menggunakan SQ-FFQ (Semi Quantitative Food Frequency Questionnaire) dan pemberian konseling gizi yang dilakukan secara home visite oleh peneliti selama kurang lebih 15 menit mengenai pola makan dan terapi diet yang tepat pada penderita dislipidemia dengan batuan leaflet, kemudian dilakukan pencatatan makan dengan menggunakan form estimated food record selama 3 hari acak, dimana hari dalam pencatatan estimated food record ditentukan oleh peneliti yaitu hari Selasa, 24 Desember 2014, hari Minggu, 28 Desember, dan Rabu, 31 Desember 2014, sedangkan pemberian jus jambu biji merah dan buah jeruk siam diberikan selama 14 hari. Berikut adalah kriteria sampel dalam penelitian ini: (1) kriteria inklusi: kelompok kontrol dan kelompok perlakuan merupakan pasien dislipidemia (dengan minimal 2 parameter profil lipid abnormal) yang bersedia menjadi sampel penelitian, berjenis kelamin wanita, responden dalam keadaan sadar dan dapat menerima makanan oral, tidak merokok, dan responden bertempat tinggal di wilayah kerja Puskesmas Cisadea Kota Malang; (2) kriteria eksklusi: penderita dislipidemia dengan komplikasi gagal ginjal akut atau gagal ginjal kronis, gangguan fungsi hepar, diabetes melitus dan jantung, serta tidak hadir saat penelitian.

Data yang diperoleh dilakukan cleaning, coding, dan tabulasi ke dalam komputer, kemudian diuji normalitasnya dengan uji
Shapiro-Wilk. Analisis deskriptif digunakan untuk melihat gambaran karakteristik subyek serta asupan makan subyek selama penelitian. Perbedaan rata-rata kadar HDL kelompok perlakuan dan kelompok kontrol diuji dengan independent t-test. Penelitian ini telah mendapatkan persetujuan dari komite etik penelitian Fakultas Kedokteran Universitas Brawijaya No. 688/EC/KEPK-S1-GZ/12/2014.

\section{HASIL PENELITIAN}

Responden pada penelitian ini berjumlah 32 orang dengan jumlah responden pada kelompok kontrol sebanyak 16 responden dan kelompok perlakuan sebanyak 16 responden.

\section{Usia Responden}

Tabel 1 menunjukkan bahwa sebagian besar responden berusia 50-59 tahun, baik pada kelompok perlakuan $(75 \%)$ maupun kelompok kontrol $(68,8 \%)$. Usia responden paling muda yaitu 40 tahun dan usia paling tua 57 tahun.

\section{Kategori Asupan Makan Responden (Intake Lemak dan Serat) sebelum Intervensi}

Asupan makan responden pada Tabel 1 menunjukkan bahwa kebiasaan makan sumber lemak pada kelompok perlakuan dan kontrol sebelum diberikan intervensi termasuk dalam kategori defisit tingkat berat yaitu $62,5 \%$. Kebiasaan makan sumber serat pada responden (kelompok control dan perlakuan) termasuk dalam kategori intake kurang (intake serat $<27 \mathrm{~g} / \mathrm{hari}$ ).

\section{Kategori Aktivitas Fisik Responden}

Berdasarkan Tabel 1 diketahui bahwa aktivitas responden rata-rata termasuk dalam kategori ringan. Pada kelompok perlakuan sebanyak 50\% dan kelompok kontrol sebanyak $62,5 \%$. 
Tabel 1. Distribusi Frekuensi Responden Berdasarkan Karakteristik

\begin{tabular}{|c|c|c|c|c|c|c|c|}
\hline \multirow{2}{*}{$\begin{array}{c}\text { Karakteristik } \\
\text { Subyek }\end{array}$} & \multicolumn{2}{|c|}{$\begin{array}{c}\text { Perlakuan } \\
(n=16)\end{array}$} & \multirow[t]{2}{*}{$\begin{array}{l}\text { Rata- } \\
\text { rata }\end{array}$} & \multicolumn{2}{|c|}{$\begin{array}{c}\text { Kontrol } \\
(\mathrm{n}=16)\end{array}$} & \multirow[t]{2}{*}{$\begin{array}{l}\text { Rata- } \\
\text { rata }\end{array}$} & \multirow[t]{2}{*}{ Keterangan } \\
\hline & $\mathbf{N}$ & $\%$ & & $\mathbf{n}$ & $\%$ & & \\
\hline \multicolumn{8}{|c|}{ Kategori Kelompok Umur } \\
\hline $40-49$ tahun & 4 & 25 & \multirow[b]{2}{*}{$\begin{array}{l}50,62 \\
\text { tahun }\end{array}$} & 5 & 31,2 & \multirow[b]{2}{*}{51,09} & *Usia $\min 40$ \\
\hline 50-59 tahun & 12 & 75 & & 11 & 68,8 & & $\begin{array}{l}\text { tahun } \\
\text { *Usia max } 57 \\
\text { tahun }\end{array}$ \\
\hline \multicolumn{8}{|c|}{ Kategori Aktivitas Fisik } \\
\hline Sangat ringan & 8 & 50 & & 6 & 37,5 & & \\
\hline Ringan & 8 & 50 & & 10 & 62,5 & & \\
\hline Sedang & - & - & & - & - & & \\
\hline Berat & - & - & & - & - & & \\
\hline \multicolumn{8}{|c|}{ Asupan Makan Sebelum Intervensi (g/hari) } \\
\hline \multicolumn{8}{|l|}{ Intake lemak } \\
\hline Lebih & - & - & \multirow{5}{*}{34,95} & - & - & \multirow{5}{*}{$\begin{array}{l}36,76 \\
\text { g/hari }\end{array}$} & \\
\hline Baik & 1 & 6,2 & & 5 & 31,2 & & \\
\hline $\begin{array}{l}\text { Defisit tingkat } \\
\text { ringan }\end{array}$ & 1 & 6,2 & & 1 & 6,2 & & \\
\hline $\begin{array}{l}\text { Defisit tingkat } \\
\text { sedang }\end{array}$ & 4 & 25,0 & & - & - & & \\
\hline $\begin{array}{l}\text { Defisit tingkat } \\
\text { berat }\end{array}$ & 10 & 62,5 & & 10 & 62,5 & & \\
\hline \multicolumn{8}{|l|}{ Intake serat } \\
\hline $\begin{array}{l}\text { Baik } \\
\text { Kurang }\end{array}$ & $\begin{array}{l}- \\
16\end{array}$ & $\begin{array}{c}- \\
100\end{array}$ & 3,34 & $\begin{array}{l}- \\
16\end{array}$ & - & $\begin{array}{l}3,03 \\
\text { g/hari }\end{array}$ & \\
\hline
\end{tabular}

Kebiasaan makan sumber lemak dengan kriteria AKG (Angka Kecukupan Gizi): >120\% AKG: intake lebih, 90119\% AKG: intake baik, 80-89\%: defisit tingkat ringan, 70-79\% AKG: defisit tingkat sedang, <70\% AKG: defisit tingkat berat, sedangkan untuk kategori intake serat baik: $\geq 27$ gram dan intake kurang: < 27 gram berdasarkan rekomendasi American Association of Clinical Endocrinologist (AACE) (2012) [5, 10].

Tabel 2. Intake Makan Responden selama Penelitian

\begin{tabular}{|c|c|c|c|c|c|c|c|}
\hline \multirow{2}{*}{$\begin{array}{c}\text { Karakteristik } \\
\text { Subyek }\end{array}$} & \multicolumn{2}{|c|}{$\begin{array}{c}\text { Perlakuan } \\
(n=16)\end{array}$} & \multirow{2}{*}{$\begin{array}{l}\text { Rata- } \\
\text { rata } \\
\text { Intake }\end{array}$} & \multicolumn{2}{|c|}{$\begin{array}{c}\text { Kontrol } \\
(n=16)\end{array}$} & \multirow{2}{*}{$\begin{array}{l}\text { Rata- } \\
\text { rata } \\
\text { Intake }\end{array}$} & \multirow[t]{2}{*}{$\mathbf{p}$} \\
\hline & $\mathrm{n}$ & $\%$ & & $\mathbf{n}$ & $\%$ & & \\
\hline \multicolumn{8}{|l|}{ Intake Lemak } \\
\hline Lebih & 4 & 25,0 & \multirow{5}{*}{$\begin{array}{l}56,30 \\
\text { g/hari }\end{array}$} & - & - & \multirow{5}{*}{$\begin{array}{l}50,42 \\
\text { g/hari }\end{array}$} & \multirow{5}{*}{0,061} \\
\hline Baik & 9 & 56,2 & & 12 & 75,0 & & \\
\hline Defisit tingkat ringan & 1 & 6,2 & & 3 & 18,8 & & \\
\hline Defisit tingkat sedang & 1 & 6,2 & & - & - & & \\
\hline Defisit tingkat berat & 1 & 6,2 & & & & & \\
\hline \multicolumn{8}{|l|}{ Intake serat } \\
\hline Baik & 16 & 100 & 26,6 & - & - & 10,6 & \multirow{2}{*}{0,00} \\
\hline Kurang & - & - & g/hari & 16 & 100 & $\mathrm{~g} / \mathrm{hari}$ & \\
\hline
\end{tabular}


Tabel 3. Analisis Rata-rata Selisih Kadar HDL Kelompok Kontrol dan Perlakuan

\begin{tabular}{|c|c|c|c|c|c|c|}
\hline \multicolumn{3}{|c|}{ Kelompok Kontrol } & \multicolumn{3}{|c|}{ Kelompok Perlakuan } & \multirow[b]{2}{*}{$\begin{array}{c}\text { P Selisih } \\
\text { Kadar HDL } \\
\text { Antar } \\
\text { Kelompok }\end{array}$} \\
\hline $\begin{array}{c}\text { Kadar } \\
\text { HDL Awal } \\
\text { (mg/dl) }\end{array}$ & $\begin{array}{c}\text { Kadar } \\
\text { HDL } \\
\text { Akhir } \\
\text { (mg/dl) }\end{array}$ & Selisih & $\begin{array}{c}\text { Kadar } \\
\text { HDL } \\
\text { Awal } \\
\text { (mg/dl) }\end{array}$ & $\begin{array}{l}\text { Kadar } \\
\text { HDL } \\
\text { Akhir } \\
\text { (mg/dl) }\end{array}$ & Selisih & \\
\hline 49,87 & 49,90 & $\pm 0,06$ & 49,50 & 50,31 & $\pm 1,06$ & $0,03^{\mathrm{a}}$ \\
\hline
\end{tabular}

Keterangan $\rightarrow \mathrm{a}$ : Independent $t$-test; $\alpha=0,05$

Kategori Asupan Makan Responden (Intake Lemak dan Serat) setelah Intervensi

Berdasarkan Tabel 2, dapat diketahui bahwa persentase intake lemak paling tinggi adalah pada kategori intake baik untuk kelompok perlakuan dengan rata-rata intake $56,30 \mathrm{~g} / \mathrm{hari}$ $(56,2 \%)$. Rata-rata untuk kategori intake baik kelompok control adalah 50,42 g/hari (75\%). Pada intake serat, $100 \%$ kelompok perlakuan berada pada kategori intake baik dengan rata-rata 26,6 g/hari. Kelompok kontrol kategori intake kurang sebanyak $100 \%$ dengan rata-rata intake $10,6 \mathrm{~g} / \mathrm{hari}$.

\section{Selisih Rata-rata Kadar HDL antara Kelompok Kontrol dan Perlakuan}

Setelah dilakukan intervensi selama 14 hari, menunjukkan bahwa pada kelompok perlakuan perbedaan kadar HDL sebelum dan sesudah perlakuan rata-rata HDL meningkat sebanyak 1,06 mg/dl, sedangkan pada kelompok kontrol rata-rata HDL meningkat sebanyak 0,06 $\mathrm{mg} / \mathrm{dl}$. Hasil analisis perbedaan selisih kadar HDL pada kelompok perlakuan setelah dilakukan uji beda menggunakan independent $t$ test terdapat perbedaan yang signifikan antara kenaikan HDL pada kelompok kontrol dan kelompok perlakuan $(\mathrm{p}<0,05)$.

\section{PEMBAHASAN}

Faktor yang Mempengaruhi Kadar HDL pada Pasien Dislipidemia

$\underline{\text { Usia }}$

Responden pada penelitian ini baik kelompok kontrol maupun kelompok perlakuan berusia 40-59 tahun. Hal ini didukung oleh penelitian yang dilakukan oleh Ratna tahun 2011 yang dilakukan di beberapa suku di Indonesia dengan menggunakan studi cross-sectional, menunjukkan bahwa pria dan wanita suku Jawa yang memiliki risiko dislipidemia berusia $>40$ tahun [11]. Pada usia dewasa 20 -30 tahun, fatty streaks (bercak sel busa berisi lemak) mulai muncul. Seiring berjalannya waktu, streaks akan mengalami penebalan mencapai $2-3 \%$ dalam satu tahun yang disebabkan karena adanya sel radang dan jaringan ikat yang tertimbun pada streaks. Sehingga, diusia tua 50-60 tahun, akan terjadi plaque atherosclerosis yang menyenbabkan peyumbatan pembuluh darah hingga 30\% dimana aterosklerosis ini merupakan penyebab utama terjadinya penyakit jantung koroner [12].

\section{$\underline{\text { Kadar HDL }}$}

Hasil analisis perbedaan kadar HDL pada kelompok perlakuan antara sebelum dan sesudah intervensi dengan menggunakan uji paired t-test tidak menunjukkan pengaruh secara signifikan $(\mathrm{p}>0,05)$, begitu pula pada kelompok kontrol dengan menggunakan uji Wilcoxon terbukti tidak ada perbedaan kadar HDL $(\mathrm{p}<0,05)$. Namun, setelah dilakukan uji beda dengan menggunakan uji independent t-test terhadap selisih kadar HDL antara kelompok kontrol dan kelompok perlakuan pada penelitian ini menunjukkan adanya perbedaan yang signifikan $(\mathrm{p}<0,05)$. Terjadi kenaikan kadar HDL sebesar 0,06 mg/dl pada kelompok kontrol.

Menurut American Association of Clinical Endocrinologist (AACE) tahun 2012 kadar HDL 60 mg/dl dapat mengurangi risiko terjadinya penyakit jantung koroner [5]. Namun, pada penelitian ini tidak terdapat responden dengan kadar HDL mencapai $60 \mathrm{mg} / \mathrm{dl}$ baik pada kelompok kontrol maupun kelompok perlakuan setelah dilakukan intervensi. Jadi dapat disimpulkan bahwa pada kelompok kontrol dan kelompok perlakuan masih memiliki risiko terjadinya penyakit jantung koroner. 
Intake Serat

Peningkatan kadar HDL pada kelompok perlakuan dan kelompok kontrol berhubungan dengan rata-rata peningkatan asupan serat responden yaitu sebelum perlakuan sebanyak 3,03 g/hari meningkat menjadi 10,6 g/hari. Pada perlakuan, terjadi kenaikan kadar HDL sebesar $1,06 \mathrm{mg} / \mathrm{dl}$, dengan peningkatan rata-rata asupan serat responden yaitu sebelum perlakuan sebanyak 3,34 g/hari meningkat menjadi 26,6 $\mathrm{g} /$ hari. Akan tetapi, intake serat pada kedua kelompok masih belum memenuhi anjuran serat yang direkomendasikan oleh American Association of Clinical Endocrinologist (AACE) tahun 2012 yaitu seseorang dengan dislipidemia membutuhkan serat larut air sebanyak 10-25 gram/hari dan serat tidak larut air 2 gram/hari sehingga total serat yang harus dikonsumsi oleh penderita dislipidemia sebanyak $27 \mathrm{~g} /$ hari [5]. Pada kelompok perlakuan, intake serat yang dikonsumsi mencapai $98,51 \%$ dari rekomendasi AACE 2012 karena adanya intervensi berupa jus jambu biji merah dan buah jeruk. Pada kelompok kontrol, intake serat yang dikonsumsi hanya mencapai 39,25\% karena pada kelompok kontrol tidak dilakukan penambahan serat berupa jus buah jambu biji merah maupun buah jeruk, hanya asupan normal serat pada kebiasaan makan sehari-hari responden.

Berdasarkan penelitian yang dilakukan oleh Waloya tahun 2013 menunjukkan bahwa asupan serat berpengaruh secara nyata terhadap kadar kolesterol darah [13]. Konsumsi serat yang kurang akan menyebabkan risiko terjadinya PJK, hal ini terkait pada kemampuan serat dalam menunda pengosongan lambung sehingga rasa kenyang menjadi lebih lama akibatnya asupan energi menjadi berkurang. Serat memiliki fungsi mengikat asam empeduyang kemudian akan dibuang melalui feses. Garam empedu yang telah diikat oleh seratakan dikeluarkan melalui feses sehingga jumlah garam em;pedu dalam hati menurun. Penurunan jumlah garam empedu dalam hati juga diikuti dengan penurunan kolesterol dalam darah karena kolesterol dibutuhkan dalam sintesis garam empedu. Pengikatan empedu menghambat kerja enzim HMG-KoA reduktase dimana jika kerja enzim ini terhambat maka pembentukan squalen, isoprene, mevalonat dan kolesterol yan berimbas pada penekanan pembentukan LDL dan VLDL tidak dihidrolisis [14].

\section{Intake Lemak}

Pada kelompok perlakuan rata-rata asupan lemak adalah 56,30 mg, sedangkan pada kelompok kontrol rata-rata asupan lemak sebanyak 50,42 mg. Anjuran konsumsi lemak menurut AKG belum sesuai (60 gram/hari pada usia 50-64 tahun). Hasil Riskesdas tahun 2013 menunjukkan bahwa proporsi nasional penduduk dengan perilaku konsumsi makanan berlemak, berkolesterol, dan makanan gorengan $\geq 1$ kali per hari sebanyak $40,7 \%$ [2]. Jenis makanan tinggi lemak yang paling banyak dikonsumsi oleh responden diantaranya adalah gorengan seperti weci, kerupuk, dan biskuit yang mengandung lemak jenuh. Lemak jenuh ditemukan dalam daging berlemak, jeroan, margarin, minyak kelapa, dan minyak palem walaupun tinggi protein, tetapi $80 \%$ dari energinya terdiri dari lemak. Lemak jenuh dapat meningkatkan absorpsi kolesterol dalam diet atau mengurangi ekskresinya. Lemak jenuh dapat merangsang produksi kolesterol secara berlebihan dalam hati atau memudahkan penimbunan kolesterol dalam dinding pembuluh darah [15]. Namun, keterbatasan pada penelitian ini salah satunya adalah tidak membedakan asupan antara lemak jenuh dan lemak tidak jenuh, sehingga peneliti tidak dapat menghitung rata-rata asupan lemak jenuh yang menjadi salah satu penyebab dislipidemia.

Menurut penelitian yang dilakukan oleh Waloya tahun 2013, asupan lemak berpengaruh secara nyata terhadap kadar kolesterol darah [13]. Konsumsi lemak yang berlebihan dapat menyebabkan penumpukan lemak di dalam tubuh yang akan meningkatkan resiko terjadinya dislipidemia karena makanan berlemak mengandung trigliserida dan kolesterol. Tubuh dapat mensintesis lebih dari setengah kebutuhan kolesterol (sekitar $700 \mathrm{mg} / \mathrm{dL}$ ), sisanya dicukupi dari asupan makanan. Hati dan usus masingmasing terhitung mensintesis $10 \%$ kolesterol [14].

\section{Aktivitas Fisik}

Selain intake lemak dan serat, aktivitas fisik juga mempunyai pengaruh yang besar 
terhadap kadar HDL. Dari hasil analisis pada kelompok kontrol, respoden dengan aktivitas fisik sangat ringan sebanyak $50 \%$, sedangkan pada kelompok perlakuan, responden dengan aktivitas fisik sangat ringan sebanyak $37,5 \%$. Jenis aktivitas yang paling banyak dilakukan oleh responden adalah tidur, menonton TV, menyapu, dan mencuci baju tanpa mesin. Setelah dilakukan uji hubungan dengan menggunakan uji Pearson, diketahui bahwa terdapat hubungan yang signifikan antara aktivitas fisik dengan kadar HDL akhir pada kelompok perlakuan $(\mathrm{p}<0,05)$.

Hasil penelitian Waloya tahun 2013 menyatakan bahwa tingkat aktivitas fisik berpengaruh secara nyata terhadap kadar kolesterol darah [13]. Aktivitas fisik akan meningkatkan metabolisme glukosa dan lemak. Peningkatan terjadi pada hormon yang memiliki peran dalam proses glikogenolisis (pemecahan glikogen) yaitu glukagon, epinefrin, dan norepinefrin. Saat melakukan aktivitas fisik, kebutuhan energi akan meningkat, sehingga bila glukosa sebagai sumber energi utama kurang mencukupi maka akan terjadi peningkatan metabolisme lemak berupa oksidasi asam lemak sebagai respon terhadap hormon epinefrin, norepinefrin, kortisol, dan hormon pertumbuhan. Hal ini menyebabkan penurunan persentase lemak tubuh.

\section{KESIMPULAN}

Ada pengaruh pemberian jus jambu biji (Psidium Guajava) dan buah jeruk siam (Citrus Nobilis) terhadap kadar HDL pasien dislipidemia di Puskesmas Cisadea Kota Malang dengan signifikansi $(p<0,05)$. Rata-rata intake makan kelompok perlakuan sebelum intervensi yaitu dari kebiasaan konsumsi sumber lemak 34,95 g/hari dan kebiasaan konsumsi sumber serat 3,34 $\mathrm{g} /$ hari. Setelah dilakukan intervensi berupa konseling gizi secara home visit serta pemberian jus jambu biji merah dan buah jeruk, terdapat perbedaan intake makan responden yang terdiri dari rata-rata tingkat konsumsi lemak 56,30 $\mathrm{g} /$ hari dan serat 26,6 g/hari. Perbedaan rata-rata intake lemak antara setelah intervensi lebih besar dari pada sebelum perlakuan hal ini ini dimungkinkan pada awal pengambilan data secara SQ FFQ bergantung pada daya ingat responden akan kebiasaan makan makanan sumber lemak kurang lebih dalam 3 bulan terakhir, tingkat motivasi responden, dan adanya kemungkinan under estimate.

Rata-rata intake makan kelompok kontrol sebelum intervensi yaitu dari kebiasaan konsumsi lemak 36,76 dan kebiasaan konsumsi sumber serat 3,03 g/hari. Setelah dilakukan intervensi berupa konseling gizi secara home visite maka intake makan responden yang terdiri dari rata-rata tingkat konsumsi lemak 50,45 $\mathrm{g} /$ hari dan serat 10,6 g/hari. Rata-rata HDL awal kelompok perlakuan $49,5 \mathrm{mg} / \mathrm{dl}$ sedangkan ratarata HDL akhir kelompok perlakuan 50,31 $\mathrm{mg} / \mathrm{dl}$. Rata-rata HDL awal kelompok kontrol 49,87 mg/dl sedangkan rata-rata HDL akhir kelompok kontrol 49,9 mg/dl.

\section{SARAN}

Peneliti yang ingin membenahi ataupun melanjutkan penelitian ini sebaiknya dilakukan perhitungan kebutuhan pasien dengan kondisi dislipidemia untuk mengukur variabel lain yang juga memberikan pengaruh terhadap kadar HDL seperti tingkat stres maupun penyakit metabolik lainnya.

\section{UCAPAN TERIMA KASIH}

Ucapan terima kasih disampaikan khususnya kepada Puskesmas Cisadea Kota Malang atas ketersediaannya menerima penulis untuk melaksanakan penelitian.

\section{DAFTAR RUJUKAN}

1. Fodor G. Primary Prevention of CVD: Treating Dyslipidemia. Clinical Evidence Handbook A Publication of BMJ Publishing Group. 2011; 83(10): 1.

2. Deparmen Kesehatan. Hasil Riset Kesehatan Dasar 2013. Kementrian Kesehatan RI; 2013.

3. Badan Penelitian dan Pengembangan Kesehatan. Data Jumlah Penyakit Dislipidemia di Kota Malang Tahun 2013. Dinas Kesehatan Kota Malang; 2013.

4. Tjandrawinata R. Dyslipidemia. Scientific Journal of Pharmaceutical Development and Medical Application. 2013; 26(1): 5.

5. American Association of Clinical Endocrinologist (AACE). Guidelines for Management of Dyslipidemia and Prevention 
of Atherosclerosis. Endrocrine Practice. 2012; 18(Suppl 1): 14.

6. Tatang. Feel Better with Fiber. Bandung: PT. Media Pangan Indonesia; 2011. 13.

7. Astawan IWS. Efek Jus Buah Jambu biji (Psidium Guajava L.) pada Penderita Dislipidemia. Calyptra: Jurnal Ilmiah Mahasiswa Universitas Surabaya. 2013; 2(1): 6.

8. Febrianto M. Pengaruh Pemberian Jus Jeruk terhadap Peningkatan Kadar Kolesterol HDL pada Tikus Sprague Dawley Hiperkolesterolemia. [Skripsi]. Semarang: Universitas Diponegoro; 2012.

9. Rusilanti. Jus Ajaib Penumpas Aneka Penyakit. Jakarta: PT. AgroMedia Pustaka; 2013. 30-31.

10. Friedayanti R, Damanik R. Hubungan Konsumsi Energi-Protein dengan Glukosa Darah dan Tekanan Darah Anak Sekolah Dasar Penerima PMT-AS di Kabupaten Kupang Propinsi Nusa Tenggara Timur. In. Media Gizi dan Keluarga. 2000; XXXIV(2): 54-61.

11. Ratna DH. Lipid Profile among Diverse Ethnic Group in Indonesia. Acta Med Indones-Indones J Intern Med. 2011; 43(1): 10.

12. Tjay TH, Rahardja K. Obat-obat Penting Kasiat, Penggunaan dan Efek-Efek Sampingnya. Jakarta: PT. Elex Media Komputindo; 2007. 572.

13. Waloya T. Hubungan antara Konsumsi Pangan dan Aktivitas Fisik dengan Kadar Kolesterol Darah Pria dan Wanita Dewasa di Bogor. Jurnal Gizi dan Pangan. 2013; 8(1): 15.

14. Murray RK, Granner DK, Mayes PA, Rodwell VW, Bani AP, Sikumbang TMN. Biokimia Harper. 25th ed. Jakarta: EGC; 2003. 254-281.

15. Marliyati A. Pemanfaatan Sterol Lembaga Gandum (Triticum sp.) untuk Pencegahan Aterosklerosis. [Tesis]. Bogor: Institut Pertanian Bogor; 2005. 40-44. 
